\author{
Alex Vilotijević \\ E-mail: vilotijevic.a@gmail.com \\ Tin Matulja \\ E-mail: tin.matulja@riteh.hr \\ Marko Hadjina \\ E-mail: hadjina@riteh.hr \\ Davor Bolf \\ E-mail: davor.bof@riteh.hr \\ University of Rijeka, Faculty of Engineering \\ Vukovarska 58, 51000 Rijeka, Croatia
}

\title{
Modern Equipment for Waste Management on Cruise Ships
}

\begin{abstract}
A larger cruise ship with more capacity enables the ship-owner to gain more profits while at the same time lowering the cost to the client. Cruise ships today have a capacity of about 5,000 passengers, and there are projects in development of cruise ships that will accommodate up to 10,000 passengers. Since such ships have to function as an independent and ecologically sustainable unit during navigation, there is a problem of waste management. This paper presents the methods and procedures for the disposal of liquid and solid waste on cruise ships in accordance with the applicable regulations. Furthermore, proposals for improving and adapting the MARPOL convention to the above trends are presented
\end{abstract}

Keywords: cruiser ship, waste management, MARPOL

\section{Introduction}

Modern cruise ships are biggest vessels of today, some of them capable of accommodating over 7000 people. So many people on one isolated unit as a ship require fast and effective waste management system. It is crucial to ensure pleasant stay for passengers same as need to satisfy environment protection criteria. Average Cruiser can generate approximately 4000 tons of gray water, 800 tons of black water and 80 tons of solid waste and slime. Great environmental concern is raised over such a great amount of waste so it needs to be roughly processed and threated before storage or release to the sea. For a long time in past there were no regulations regarding the pollution from the ships. For last 30 years, laws and regulations had been formed in order make ships more ecologically acceptable. Today most of the ships are under 
influence of MARPOL convention which is accepted from most countries of the world. Modern waste management, Fig. 1, systems are efficient and able to satisfy latest and most strict regulations and criteria.

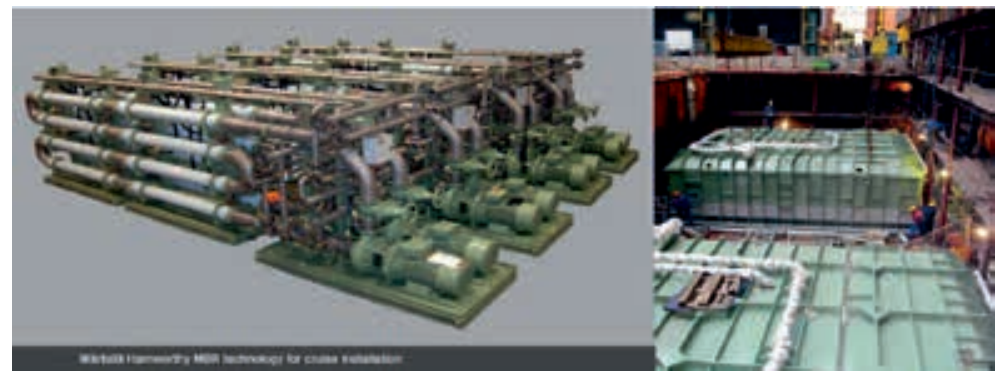

Figure 1: Wartsila Hamworthy - Membrane Bioreactor [1]

Helcom standard covers special set of rules regarding release of waste waters into Baltic Sea, by Helsinki convention, Polar cruise lines are rising in popularity in last decade. One of popular destinations are often northern parts of Baltic Sea, designated as a special area in 2010. Latest enforcements are set to take force on $1^{\text {st }}$ June 2021 for all existing IMO registered passenger ships, with need for AWP systems satisfying HELCOM standard. Otherwise, higher treatment level in general is needed in order to remove nutrients to varying degrees (depending on equipment). By April 2017, 52 different advanced water treatment systems from five manufactures (Scanship, Evac, Aco Marine, Rochem TS and Martin Membrane Systems) are approved to fulfill the requirements of Passenger Ships operating in MARPOL Annex IV special areas [2]. Figure 2 presents AWP installations done by Scanship.

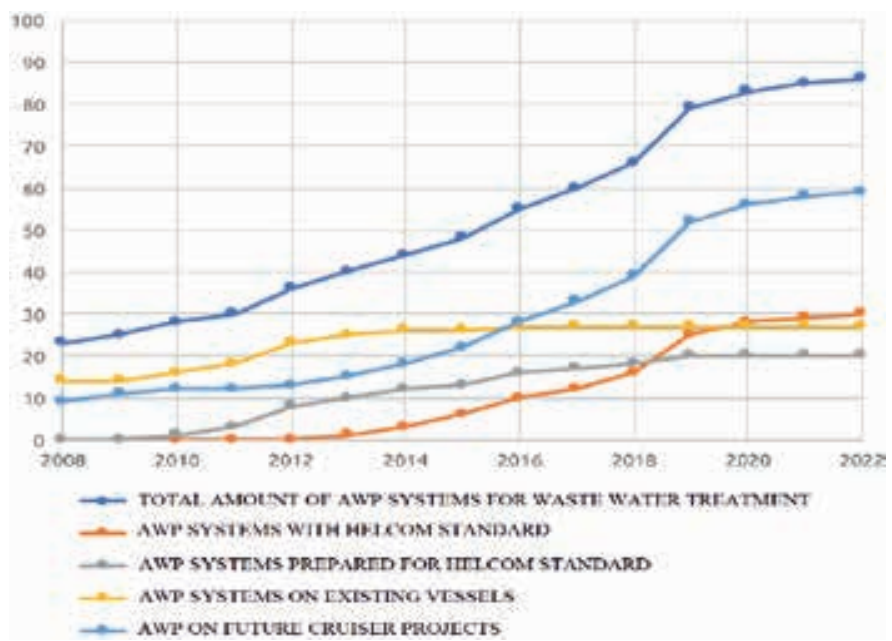

Figure 2: Advanced Water Purification System installations [3] 


\section{MARPOL Convention}

MARPOL Convention (Marine Pollution Convention) is an international convention for prevention of pollution by ships. It includes waste as waste waters and solid waste, same as discharge oils and air pollution by exhaust gasses with intention to completely prevent pollution by any of those substances. MARPOL was signed on $17^{\text {th }}$ February 1973 . And until this day there are 156 states of the world backing it, what makes $99,42 \%$ of world fleet. All vessels sailing under MARPOL backing states flags are obligatory to satisfy regulations given by it. MARPOL is divided in more subcategories (Annexes), and every one of them is narrowed to a group of ship pollutants. Following annexes are most relevant for cruise ships.

Annex I - Prevention of oil and oily waters pollution

Came into force on $2^{\text {nd }}$ October 1983. It covers problem of oil pollution and also includes older criteria OILPOL from 1954. Two parts of Annex I are formed. The first part refers to engine room waste waters and following equipment as separators, scales and pumps. The second part refer to ballast tanks and cargo spaces that are also risky of oil pollution. Integrated part of Annex I is "Oil record book" which is used to register all the data about discharging oils.

Annex IV - Prevention of waste water pollution

Group of regulations regarding adequate equipment and systems of waste water management before of their release into sea or transfer to port tanks. Latest amendments are regulating all vessels of 400 brut tons capable of carrying more than 15 people. Ships need to have waste water management system, disinfection equipment or storage tanks. Release of untreated waters is only possible when it had passed densification process on distances greater than 3 nautical miles from nearest land. In case of completely untreated waste waters distance must be greater than 12 nautical miles from nearest lad with controlled discharge speed and sailing speed not less than 4 knots. Release of wastewaters trough approved management system is possible at all locations considering there are no visible particles nor color change of surrounding sea.

Annex V-Prevention of solid waste pollution

Sets rules regarding all forms of solid waste produced on the ship. Nondissolvable and toxic materials make the biggest problem. Those materials are strictly banned for sea discharge, such as plastics, synthetic ropes, incinerator ashes, kitchen oil, paper, metal parts, and bottles of any kind and similar. Some sorts of waste can be discharged, such as food waste, nontoxic hygienic substances and animal carcasses. Even though Annex V is not obligatory, it is accepted by 150 signing countries of MARPOL. Several amendments had been proposed, [4]. 


\section{Waste waters}

Cruise ships are getting bigger and passenger capacity of a modern cruise ship will soon reach 10000 people. Ships like those are often on their routes in highly protected areas as Alaska, Northern Sea and Mediterranean in which waste water release is highly restricted. In order to treat waste correctly, shipbuilding industry and manufactures of ship equipment are developing systems that ensure adequate treatment of waste to satisfy MARPOL regulations. Waste waters are divided on black and gray waters. Black (fecal) waters come from toilets and ships hospital while gray waters come from showers, sinks, kitchen equipment and similar. Waste water treatment is complex process divided on several stages, Fig. 3.

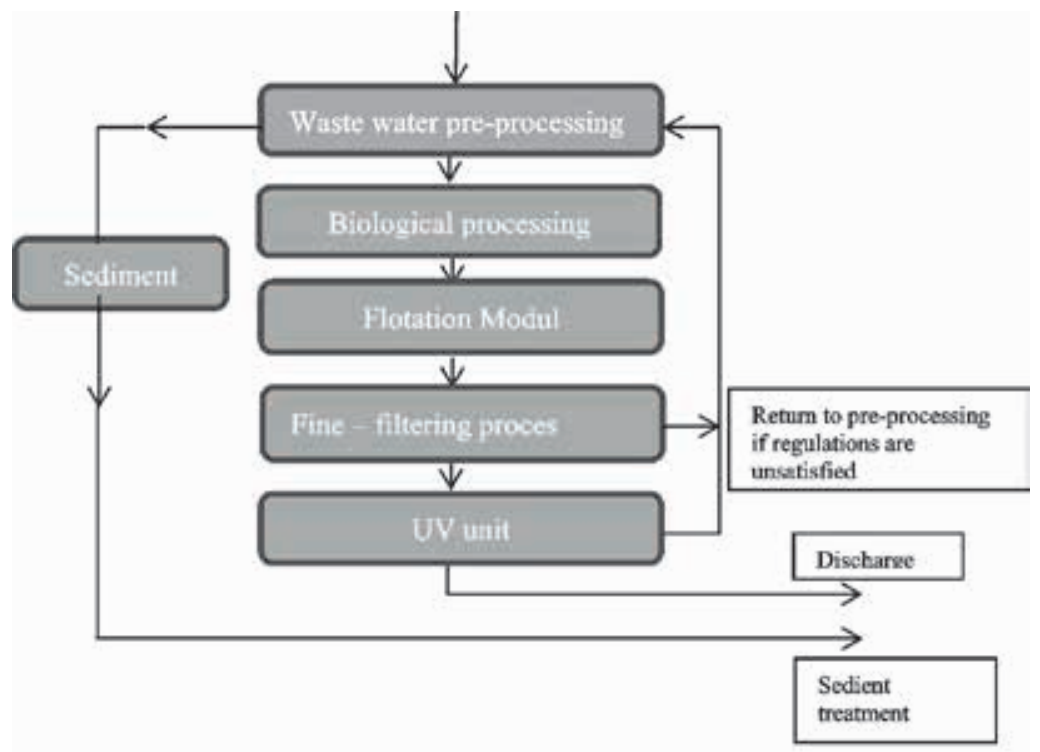

Figure 3: Waste water treatment stages

\subsection{Waste water pre-processing}

Pre-processing unit is first of five stages in waste water treatment. This unit mechanically purifies and separates bigger particles and solid grease. Main function of pre-processing is to prevent equipment damage in further treatment stages or pipe clogging by pieces of plastic or paper, cigarette butts and similar. 
Process is based on constantly rotating filter nets, separating bigger particles from the rest of the water. Collected solids are removed by automatic scraper and transferred to sediment tank for further treatment.

\subsection{Biological procesing}

After leaving the pre-processing unit, waste water is brought to mixing tank for biological decomposition by microorganisms and oxidation Compressor is constantly pumping air into tank to prevent organic matter to sediment and to ensure oxidation. Most of organic matter decomposes in this stage.

\subsection{Floculation unit}

Flocculation is special process in which several chemicals like iron chloride and aluminum sulfite are used to connect and coagulate smaller organic particles into bigger fragments in order to ensure easy removal in flotation stage. In addition, in this stage $\mathrm{pH}$ control takes place. In order to discharge the waters at the end of the process, its $\mathrm{pH}$ value must be between 6 and 9. Gray waters form ships kitchen can cause problem since it loses its $\mathrm{pH}$ value due to boiling. There is an integrated device on flocculation unit. It is monitoring $\mathrm{pH}$ value and is connected to chemical pumps while maintaining satisfying value.

\subsection{Floatation stage}

Flotation is process used to remove previously created fragments in flocculation unit. Pressure chamber is used to blow air at 4 to 6 bars to achieve water dispersion. Formed air bubbles surround organic particles and force them to float up to the surface from where are easily removed and moved to sediment tanks, Fig. 4.
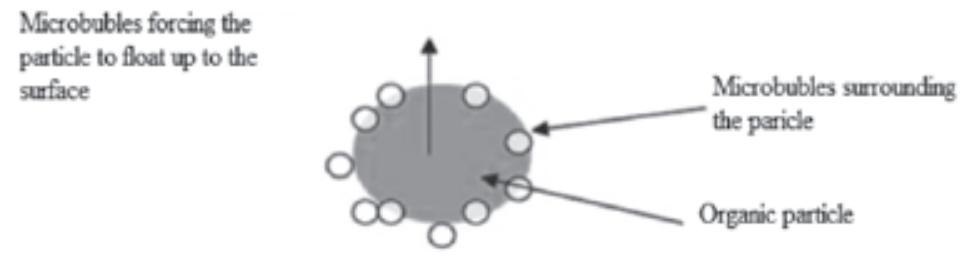

Figure 4: Fragment flotation principle [5]

\subsection{Fine filtering process}

Oval filters with net grade of 40 to $60 \mu \mathrm{m}$ are able to remove last remaining particles. Filter is constantly washed with clean water to ensure flawless filtering. 
Chlorine is added as disinfectant if needed, but modern systems mostly have an integrated UV module, functioning without any addition of chemicals.

\subsection{UV (Ultra violet) module}

After fine filtering, treated and purified water is pumped through set of UV laps, Fig. 5. This module is used to disinfect water in order to remove all the remaining organisms, bacteria and viruses. Modern systems have an $99,9 \%$ efficiency and are ecologically acceptable since there are no added chemicals like chlorine.

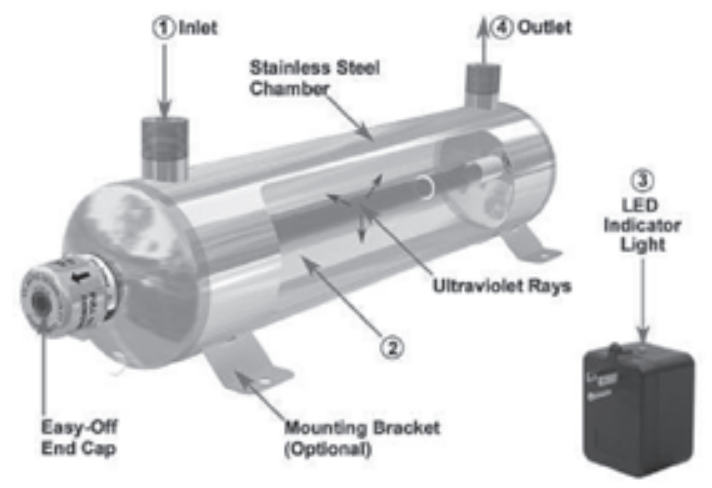

Figure 5: UV module, final treatment stage [6]

\subsection{TSS module}

Before treated waste, water can be discharged to sea, same flows through TSS (Total Suspended Solids) module. TSS module measures pollutants in water in TSS index. In order to discharge treated water, TSS index must be lower than 35 milligrams per liter. In case of unsatisfying index results, water returns to fine filtering process, Fig. 6 .

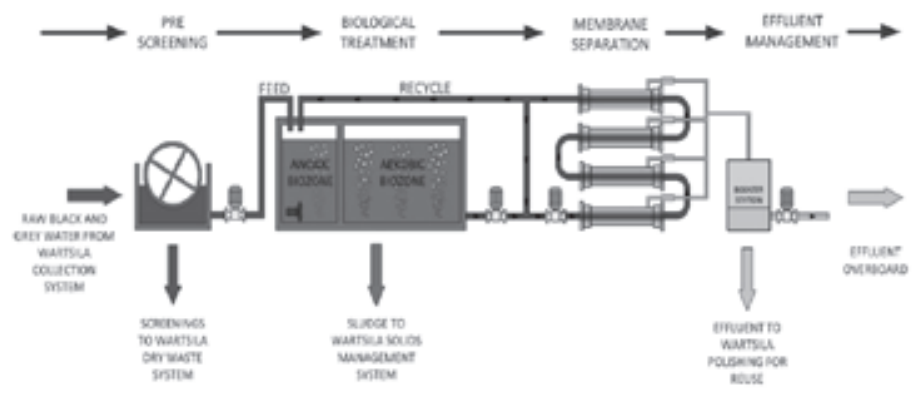

Figure 6: Wartsila Hamworthy waste water management system [1] 


\section{Sold waste}

In addition to wastewater, large cruise ships also produce a large amount of solid waste, Fig. 7. Solid waste can be divided into several categories such as: plastics, food waste, general waste, operational waste, and kitchen oil and incinerator ashes. Incinerator is used to burn various waste in order to reduce amount of space needed to store produced waste, same as to lower expanses of waste disposal at port. Sediment and sludge from waste water treatment system is also considered as solid waste and is burnt in ships incinerator after it goes through complete drying process. Various presses are also used to reduce waste volume.

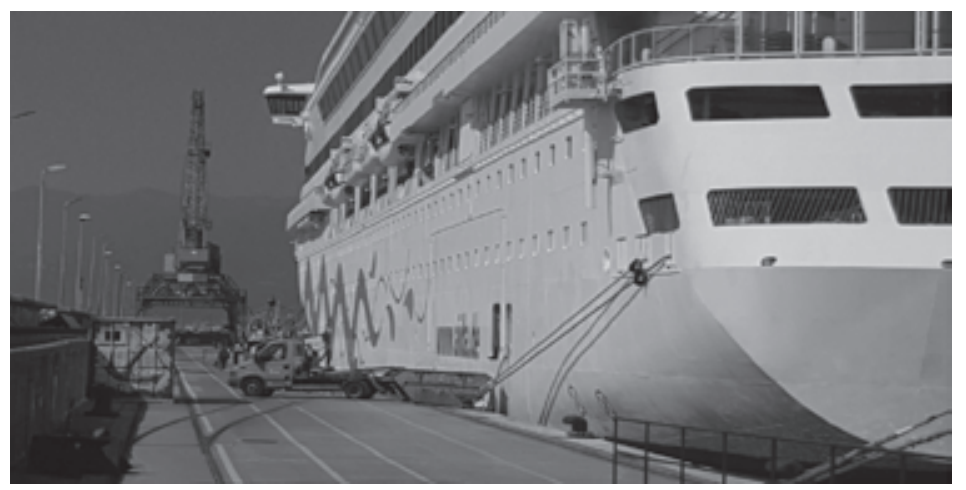

Figure 7: Cruise ship Aida Aura disposing compacted waste at port of Rijeka, Croatia

\subsection{Plastics waste}

Plastic waste is generated in large amount on bigger cruise ships, mostly from regular waste and ships kitchen. Most common plastics are wrappings, bottles, synthetic ropes, plastic bags and similar. Plastics are also divided as contaminated and uncontaminated by means of plastics that had contact with food. Reason for this comes with concern for pathogens left from food so contaminated plastics are separately stored. According to MARPOL Annex VI there is a restriction for burning PVC in ships incinerator unless the incinerator is verified with IMO certificate.

Instead of incinerator, various grinders and presses are used to reduce plastic volume, which is important since ports accept waste by calculating unit of volume. On average cruise ship accommodating four to six thousand passengers, 100 cubic meters of waste plastics are produced every day. 


\subsection{Food waste}

Food waste on cruise ships is accumulated in kitchens and restaurants. IMO classifies waste food as all fresh or rotten substances including fruits, vegetables, processed foods, meat and all of the food remains. Further, those are divided on soft and solid substances (bones). Waste food is allowed for discharge at sea at distances greater than 12 nautical miles from closest land in case when all the plastics are separated form organic waste. Anyhow, most of the waste food is burnt in ship incinerator it is fitted on board. Food waste storage on board must be perfectly arranged, not to compromise crew and passenger health and pleasant stay.

Average cruise ship produces about 23 kilograms of waste food per passenger on weekly basis. Waste food stations are arranged across the ship on all required decks, where from all the waste is gathered in one station for separation of soft substances from bones. Bones later get placed into special bone grinders in order to prevent clogging in pipes transporting waste to ships incinerator, Fig. 8.

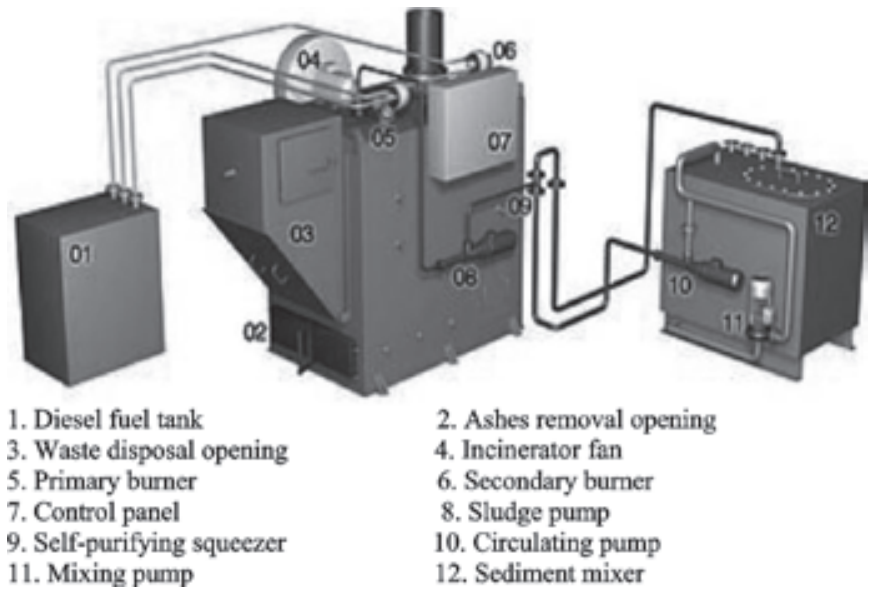

Figure 8: Incinerator system parts [7]

\subsection{General and operational waste, kichen oil and incinerator ashes}

General waste on ship is all the waste accumulated mostly on passenger areas, excluding waste food, plastics, and kitchen oil. IMO defines this waste type as "all the waste types not covered by MARPOL Annexes and are accumulated in ships accommodation areas" mostly considering paper, cardboard, synthetic materials, foils, cans, wrappings and glass. Processing equipment includes various presses depending on waste type, glass crusher and incinerator for burning of paper and cardboard. Waste 
often gets separated to simplify disposal at port. In average $70 \%$ of waste in this category is burnt and rest is pressed for volume reduction. In average, every passenger produces about 0.9 kilograms of general waste on daily basis, which makes about five tons for larger class cruise ship.

Operational waste on cruise ship accumulates mostly in ships engine room or during the maintenance of ships systems at sea. Since it could include various harmful chemicals it needs to be promptly separated. Oily rags, batteries, oil packages, wood, paints, asbestos and outdated pyrotechnics are all classified as operational waste. It mostly gets pressed and stored in special holds due to hazardous content. If separated, part of waste can be burnt in incinerator (oily rags and paper).

Kitchen waste oil is mostly stored in special separate tanks. Large cruise ships accumulate great amounts of kitchen oil so it is often mixed with waste sludge but this approach breaks the rules of MARPOL Annex V. Kitchen oil tanks often have a capacity up to $1000 \mathrm{~m}^{3}$, which are emptied at port. Kitchen oil disposal is often free since it can be used as basis for bio-fuels.

Incinerator ashes are considered harmful since it contains sludge and sediment ash. Automated incinerator system packs ash into special bags, which are placed in metal boxes easy to store. All ash is disposed at port and doesn't undergo any further treatment.

\section{Conclusion}

Ecological consciousness is on the rise in last decade, since the lack of environmental regulations in past century took its toll on the environment.

Luckily, with rising popularity of cruise ships, environmental regulations are rewritten and became stricter. Today MARPOL regulations ensure no cruise ship present a potential danger for the environment due to impropriate waste disposal. As the latest cruise ships are built bigger, waste management equipment manufacturers are keeping up by designing more advance systems. Most of those systems are completely autonomous and have no need for additional crew on board for maintenance. Anyhow, biggest threat to marine pollution comes from smaller vessels not falling under MARPOL convention (smaller of 400 tons brut, carrying less than 15 people).

Especially in closed seas as the Mediterranean, with plenty of touristic destinations on its shore. Those vessels regularly discharge untreated waste waters same as solid waste since there is no storage areas on board. During the touristic seasons, number of those vessels is drastically high and causes a rising pollution problem. Therefore, a special set of regulations should be made, dealing with this problem. Possibly in form of waste disposal logbooks and installation of waste water tanks as an obligatory feature. 


\section{References}

1. Wartsila: https://www.wartsila.com/marine/build/waste-treatment/waste-water-processing/sewagetreatment-plants

2. HELCOM: http://www.helcom.fi/action-areas/shipping/sewage-from-ships/on-board-sewagetreatment

3. Scanship: https:/www.scanship.no/marine/marine-systems/

4. IMO: http://www.imo.org/en/About/Conventions/ListOfConventions/Pages/InternationalConvention-for-the-Prevention-of-Pollution-from-Ships-(MARPOL).aspx

5. Mario Jelic, Damir Mage: "Environmental systems on large passenger ships"

6. Atlantic Ultraviolet Corporation: https://ultraviolet.com/

7. Majelić: PP presentation http://www.unidu.hr/datoteke/majelic/ZMMO-8-BS-N.pdf 